\title{
Understanding Variation in Managers' Ambidexterity: Investigating Direct and Interaction Effects of Formal Structural and Personal Coordination Mechanisms
}

\author{
Tom J. M. Mom, Frans A. J. van den Bosch, Henk W. Volberda \\ Department of Strategic Management and Business Environment, Rotterdam School of Management, \\ Erasmus University, 3000 DR Rotterdam, The Netherlands \\ \{tmom@rsm.nl, fbosch@rsm.nl, hvolberda@rsm.nl\}
}

\begin{abstract}
$P^{\prime}$ revious research focuses on firm and business unit level ambidexterity. Therefore, conceptual and empirically validated understanding about ambidexterity at the individual level of analysis is very scarce. This paper addresses this gap in the literature by investigating managers' ambidexterity, delivering three contributions to theory and empirical research on ambidexterity: first, by proposing three related characteristics of ambidextrous managers; second, by developing a model and associated hypotheses on both the direct and interaction effects of formal structural and personal coordination mechanisms on managers' ambidexterity; and third, by testing the hypotheses based on a sample of 716 business unit level and operational level managers.

Findings regarding the formal structural mechanisms indicate that a manager's decision-making authority positively relates to this manager's ambidexterity, whereas formalization of a manager's tasks has no significant relationship with this manager's ambidexterity. Regarding the personal coordination mechanisms, findings indicate that both the participation of a manager in cross-functional interfaces and the connectedness of a manager to other organization members positively relate to this manager's ambidexterity. Furthermore, results show positive interaction effects between the formal structural and personal coordination mechanisms on managers' ambidexterity. The paper's theoretical contributions and empirical results increase our understanding about managers' ambidexterity and about how different types and combinations of coordination mechanisms relate to variation in managers' ambidexterity.
\end{abstract}

Key words: ambidexterity; manager level; coordination mechanisms; interaction effects History: Published online in Articles in Advance April 27, 2009.

As current literature focuses on ambidexterity at the business unit and firm level of analysis, conceptual and empirically validated understanding about ambidexterity at the individual level of analysis is very scarce (Raisch and Birkinshaw 2008). Hence, scholars like Gupta et al. (2006, p. 703) and Raisch and Birkinshaw (2008, p. 397) suggest investigating ambidexterity at the individual level of analysis as a promising direction for future research. This paper addresses this gap in the literature by investigating managers' ambidexterity. Existing studies refer to ambidexterity as a firm's or business unit's ability to combine exploration and exploitation related activities (e.g. Gibson and Birkinshaw 2004, O'Reilly and Tushman 2004). Based on these literatures, we define ambidexterity at the manager level as a manager's behavioral orientation toward combining exploration and exploitation related activities within a certain period of time (cf. Gibson and Birkinshaw 2004, p. 210; O'Reilly and Tushman 2004, p. 81; Tushman and O'Reilly 1996, p. 24).

The relevance of investigating managers' ambidexterity is emphasized by studies that discuss a firm's ability to become ambidextrous in terms of, for instance, managers' decision-making processes (Rivkin and Siggelkow 2003), the extent to which managers engage in routine and nonroutine activities (Adler et al. 1999), or managers' collective and creative actions (Sheremata 2000). In line with these authors, O'Reilly and Tushman (2004, p. 81) conclude that "one of the most important lessons is that ambidextrous organizations need ambidextrous senior teams and managers." These examples illustrate the importance of increased understanding about ambidexterity at the manager level of analysis and about what drives variation in managers' ambidexterity.

Although some studies provide valuable examples of managers' ambidextrous behavior (e.g., O'Reilly and Tushman 2004, Tushman and O'Reilly 1996), ambidexterity research at this level of analysis would benefit from further conceptualization. We contribute to this effort by proposing and clarifying three related characteristics of ambidextrous managers: ambidextrous managers host contradictions (Smith and Tushman 2005, Tushman and O'Reilly 1996); they are multitaskers (Birkinshaw and Gibson 2004, Floyd and Lane 2000); and they both refine and renew their knowledge, skills, 
and expertise (Floyd and Lane 2000, Hansen et al. 2001, Sheremata 2000).

The paper also delivers a contribution to our understanding about what drives variation in managers' ambidexterity by developing a model and testing hypotheses on the relations between managers' ambidexterity and two generic types of coordination mechanisms, formal structural and personal coordination mechanisms. Previous research indicates the importance of these two types of coordination mechanisms as key organizational elements that influence managers' behavior by shaping their relations and their interactions with other individuals, groups, or organization units (e.g., Martinez and Jarillo 1989, Van De Ven et al. 1976). The importance of both types of coordination mechanisms is also reflected in the literature on ambidexterity (Raisch and Birkinshaw 2008). Whereas some investigators highlight the importance of formal structural mechanisms for a firm's pursuit of ambidexterity (e.g., Benner and Tushman 2003, Duncan 1976), others illustrate the importance of more personal relationships among organization members (e.g. Gibson and Birkinshaw 2004, Sheremata 2000). Studies on coordination indicate that different types of coordination mechanisms may differently affect organization members' behavior (e.g., Daft and Lengel 1986, Van De Ven et al. 1976). However, much more remains to be understood about whether and how the two different types of coordination mechanisms differently relate to managers' ambidexterity (Jansen et al. 2006).

Several studies on ambidexterity argue that combining different organizational elements may stimulate organization members' ambidexterity, for example, combining "hard elements" and "soft elements" (Gibson and Birkinshaw 2004, p. 213) or combining "centrifugal" and "centripetal" elements (Sheremata 2000). However, both conceptual and empirically validated insight on the combined effect of such different organizational elements on ambidexterity is scarce (Raisch and Birkinshaw 2008, Rivkin and Siggelkow 2003). To contribute to this issue both theoretically and empirically, we will develop and test hypotheses not only on the direct relations between both types of coordination mechanisms and managers' ambidexterity but also on the interaction effects between the two types of mechanisms. With respect to the interaction effects, Raisch and Birkinshaw (2008, p. 399) explicitly suggest that "future research could formally develop and test propositions on how different antecedents interact and complement one another in a firm's pursuit of organizational ambidexterity."

Summarizing, this paper aims to deliver three contributions to the literature on ambidexterity: first, by proposing and clarifying three related characteristics of ambidextrous managers by integrating insights from previous studies; second, by developing a model and associated hypotheses on both direct and interaction effects of formal structural and personal coordination mechanisms on managers' ambidexterity; and third, by testing the hypotheses based on a sample of 716 managers. In the next section, we elaborate on the concept of managers' ambidexterity and develop the model and associated hypotheses. The methods section provides details about the sample, data collection, and the development and validation of the measurement instrument. Next we present the empirical findings and conclude with a discussion of the results, implications, and issues for further research.

\section{Theory and Hypotheses}

\section{Managers' Ambidexterity}

Based on reviewing and integrating insights from previous studies we propose the following three related characteristics of ambidextrous managers: First, ambidextrous managers host contradictions (Smith and Tushman 2005, Tushman and O'Reilly 1996). That is, they have the motivation and ability to be sensitive to, to understand, and to pursue a range of seemingly conflicting opportunities, needs, and goals (O'Reilly and Tushman 2004). Related to this, previous research points out the need for ambidextrous managers to deal with conflict (Duncan 1976, Floyd and Lane 2000) and to engage in paradoxical thinking (Gibson and Birkinshaw 2004, Smith and Tushman 2005). Examples from the literature that illustrate this characteristic indicate that ambidextrous managers search for new market needs and technological opportunities while also being sensitive to reinforce existing product-market positions (Burgelman 2002, Tushman and O'Reilly 1996); they both elaborate on existing goals, beliefs, and decisions and reconsider these (cf. Ghemawat and Ricart I Costa 1993, Rivkin and Siggelkow 2003); and they have both a short-term and a long-term orientation towards identifying and pursuing opportunities (O'Reilly and Tushman 2004).

Second, ambidextrous managers are multitaskers; i.e., they fulfill multiple roles and conduct multiple different tasks within a certain period of time (Birkinshaw and Gibson 2004, p. 45; Floyd and Lane 2000). Related to this, authors indicate that ambidextrous managers are more generalists rather than more specialists (Birkinshaw and Gibson 2004, Leana and Barry 2000). The literature illustrates this characteristic by indicating that ambidextrous managers fulfill multiple roles related to both competence deployment and competence definition activities (Floyd and Lane 2000, Sanchez et al. 1996), conduct both routine and nonroutine activities (Adler et al. 1999), carry out both creative and collective actions (Sheremata 2000), and typically act outside the narrow confines of their own job (Adler et al. 1999, Gibson and Birkinshaw 2004).

Third, ambidextrous managers both refine and renew their knowledge, skills, and expertise (Floyd and Lane 
2000, Hansen et al. 2001, Sheremata 2000). Related to this, prior research indicates the importance for ambidextrous managers to acquire and process different kinds of knowledge and information (Floyd and Lane 2000, Sheremata 2000). Examples from the literature illustrate that ambidextrous managers engage in both reliability-enhancing and variety-increasing learning activities (Holmqvist 2004, McGrath 2001), process and acquire both explicit and tacit knowledge (Lubatkin et al. 2006, Nonaka and Konno 1998), and engage in both local and distant search for knowledge and information within their network of contacts (Hansen et al. 2001, Subramaniam and Youndt 2005).

\section{Direct Impact of Formal Structural Coordination Mechanisms on Managers' Ambidexterity}

Formal structural coordination mechanisms are one of the most important mechanisms for coordinating activities. We focus in this study on decentralization and formalization because these emerge most consistently in studies of the components of the formal structure (Miller and Dröge 1986). Furthermore, by focusing on decentralization and formalization, we follow other studies that also investigate formal structural coordination mechanisms (e.g., Jansen et al. 2006, Zmud 1982). To investigate decentralization at the manager level of analysis, we focus on a manager's decision-making authority (Ghoshal et al. 1994, Sheremata 2000). To investigate formalization at the manager level of analysis, we focus on the extent of formalization of a manager's tasks, i.e., on the degree to which rules and codes describe a particular task, and the degree to which the manager has to conform to the task description (Hage 1965, Pugh et al. 1963).

A Manager's Decision-Making Authority. A manager's decision-making authority is about the extent to which a manager has decision-making authority over how and which tasks the manager performs and his or her ability to solve problems and to set goals (AtuaheneGima 2003, Dewar et al. 1980). Increasing managers' decision-making authority increases their sense of responsibility for how they conduct their tasks and the performance of these tasks (Tushman and O'Reilly 1996, Zmud 1982). This stimulates their willingness to become aware and recognize a larger diversity of organizational, market, and technological opportunities and needs and to become more sensitive to understanding how to act upon these different opportunities and needs (Miller 1987, Pierce and Delbecq 1977, Tushman and O'Reilly 1996). For instance, studies indicate that increasing managers' decision-making authority triggers them not only to focus on short-term needs and associated benefits but also to increasingly attend to opportunities that will define the future (Pierce and Delbecq 1977, Zmud 1982) and to the associated long-term benefits
(Miller 1987, O'Reilly and Tushman 2004). Related to this, others indicate that increasing managers' decisionmaking authority increases their urge to seek solutions to problems both within and outside the framework of the existing strategy and beliefs (Ghemawat and Ricart I Costa 1993, Sheremata 2000).

Furthermore, increased decision-making authority increases managers' self control and ownership of tasks and decisions (Hage and Aiken 1967, Tushman and O'Reilly 1996), which enables them to act upon the recognized diversity of opportunities and needs and to actively pursue a range of diverse goals (O'Reilly and Tushman 2004, p. 81), i.e., to act ambidextrously. As Gibson and Birkinshaw (2004, p. 211) put it, increased self control and ownership augments managers' ability "to make their own choices as to how they divide their time between alignment- and adaptability-oriented activities," and it increases their aspiration to attain to both efficiency and flexibility related goals (Adler et al. 1999). Finally, due to increased decision-making authority, managers have to rely more on their own skills and expertise rather than on rules or the skills and expertise of superiors (Hage and Aiken 1967). This increases these managers' motivation to refine their existing skills and expertise as well as to develop new skills and expertise (Crossan and Berdrow 2003, McGrath 2001, Floyd and Lane 2000). These arguments suggest the following hypothesis.

HYPOTHESIS 1. A manager's decision-making authority will be positively related to this manager's ambidexterity.

Formalization of a Manager's Tasks. Formalization of a manager's tasks refers to the degree to which rules and codes describe a particular task; provide guides for decision making; and provide guides for conveying decisions, instructions, and information and the degree to which the manager has to conform to the task description (Hage 1965, Pugh et al. 1963). Increasing formalization of managers' tasks increases the possibility that these managers become less receptive to decisionmaking stimuli that are not monitored by formal systems (Cyert and March 1963). Hence, higher levels of formalization are associated with singleness of purpose (Pierce and Delbecq 1977); they decrease the range of different opportunities and goals managers are likely to pursue (Hage 1965, Miller 1987). This formalization is negatively associated with their level of ambidexterity; ambidextrous managers pursue a range of different goals (Tushman and O'Reilly 1996) and "have the ability to understand and be sensitive to the needs of very different kinds of business" (O'Reilly and Tushman 2004, p. 81).

Moreover, for being able to pursue a range of different goals and to deal with associated conflicts (Floyd and Lane 2000), ambidextrous managers need to cooperate and to "combine their efforts" with other organization members (Birkinshaw and Gibson 2004, p. 49; 
Duncan 1976, p. 181). However, increasing formalization of tasks increases managers' sense of isolation resulting from difficulties with comprehending the relationship between their tasks and a larger purpose (Organ and Greene 1981). This may result in a reduced motivation to cooperate and combine efforts with others (Hage and Aiken 1969, Pierce and Delbecq 1977). Increasing formalization of managers' tasks also necessitates that they develop more expertise in a limited area (Hage 1965); it augments these managers' level of specialization and their depth of knowledge within the confines of the formalized tasks (Daft and Lengel 1986, Zander and Kogut 1995). This reduces these managers' ability to act ambidextrously and to act outside the narrow confines of their jobs (Adler et al. 1999). It also makes it more difficult for them to broaden their range of skills (Daft and Lengel 1986), i.e., to be "more generalist" rather than "more specialist" (Birkinshaw and Gibson 2004). These arguments suggest the following hypothesis.

HYPOTHESIS 2. Formalization of a manager's tasks will be negatively related to this manager's ambidexterity.

\section{Direct Impact of Personal Coordination Mechanisms on Managers' Ambidexterity}

Besides formal structural coordination mechanisms, the literature emphasizes the importance of "personal types" (Cray 1984, p. 87) of coordination mechanisms. Such coordination mechanisms comprise personal relationships between organization members that typically cut across organizational units and hierarchical levels and include "direct contact, liaison roles, task forces, and teams" (Galbraith 1973, p. 89; see also Egelhoff 1991, Martinez and Jarillo 1989). Liaison roles, task forces, and teams are more formal personal coordination mechanisms (Gupta and Govindarajan 2000) as compared to direct contacts, which are more informal and voluntary modes of personal coordination (Tsai 2002). In this study, we consider both types of personal relationships by investigating participation in cross-functional interfaces by a manager, i.e., liaison roles, task forces, and teams (cf. Gupta and Govindarajan 2000), and a manager's direct contacts in terms of the manager's connectedness to other organization members (cf. Jaworski and Kohli 1993).

Participation in Cross-Functional Interfaces by a Manager. Cross-functional interfaces encompass lateral integration mechanisms such as liaison personnel, task forces, and teams (Galbraith 1973, Gupta and Govindarajan 2000). Participation of managers in crossfunctional interfaces increases their cooperation with other managers of different functions, units, and hierarchical levels (Galbraith 1973, Miller 1987). These other managers are likely to differ in their relationship to the firm's existing strategy, goals, interests, time horizon, core values, and emotional tone (Floyd and Lane 2000,
Whetten 1978). Hence, besides bringing in their own specialized expertise, and besides representing the interest of their own specific group, managers who participate in cross-functional interfaces also have to think and act outside the narrow confines of their own job and position; i.e., they have to understand and take into consideration the interests, perspectives, beliefs, and values of other managers (Duncan 1976, Floyd and Lane 2000, Miller 1987).

Furthermore, cross-functional interfaces increase trust between managers of differentiated units (Adler et al. 1999, Galbraith 1973), which is "a critical contextual factor" for managers to "shift the tradeoff between efficiency and flexibility" (Adler et al. 1999, p. 63). It creates a supportive context for managers with different backgrounds to cooperate and learn from each other (Gibson and Birkinshaw 2004). Related to this, Duncan (1976) points out that participation in cross-functional interfaces enables managers' ambidextrous behavior by allowing them to confront and resolve conflicts regarding different goals, needs, and interests between differentiated organizational units and hierarchical levels. Managers' participation in cross-functional interfaces also positively relates to their ambidexterity by offering opportunities to exchange knowledge (Egelhoff 1991, Gupta and Govindarajan 2000). Cross-functional interfaces offer opportunities for managers to refine their existing knowledge by acquiring knowledge that is related to their own knowledge base. These interfaces serve, for instance, as mechanisms to exchange knowledge and information regarding best practices of related technologies, processes, or markets, allowing managers to increase or refine their skills and expertise in a limited or specialized area (Henderson and Cockburn 1994, Jansen et al. 2005). At the same time, by participating in crossfunctional interfaces, managers renew their knowledge base by acquiring new or unrelated knowledge from managers with different expertise (Egelhoff 1991, Ghoshal and Bartlett 1988). These arguments suggest the following hypothesis.

HyPOTHESIS 3. Participation in cross-functional interfaces by a manager will be positively related to this manager's ambidexterity.

Connectedness of a Manager to Other Organization Members. Connectedness of a manager relates to the extent to which the manager is networked to other organization members across hierarchical levels and organizational units in terms of direct personal contacts (Jaworski and Kohli 1993, Sheremata 2000). It refers to the size of the manager's network of direct contacts across hierarchical levels and organizational units and to the pattern of the manager's network in terms of density (Jansen et al. 2006, Jaworski and Kohli 1993, Sheremata 2000). An increasing size of a manager's network of direct contacts across hierarchical levels and organizational units is 
associated with increasing possibilities for that manager to identify and acquire knowledge for both exploration and exploitation purposes (Hansen et al. 2001, p. 26; Nahapiet and Ghoshal 1998, p. 248; Subramaniam and Youndt 2005). A manager may benefit from using network contacts by acquiring new and diverse knowledge to, for instance, develop new competences (Floyd and Lane 2000), pursue radical innovations (Subramaniam and Youndt 2005), or find innovative solutions to problems (Sheremata 2000). A manager may also benefit from using network contacts by obtaining related and complementary knowledge to, for instance, improve and refine existing competences (Floyd and Lane 2000), pursue incremental innovations (Subramaniam and Youndt 2005), or reinforce existing beliefs and decisions (Rivkin and Siggelkow 2003).

Increasing levels of density of direct personal contacts within a manager's network is associated with an increased ability by that manager to acquire and understand complex and ambiguous knowledge from the network contacts (Hansen et al. 2001) and to engage in reciprocal, nonroutine information processing (Daft and Lengel 1986, Egelhoff 1991). These characteristics enable that manager to reduce equivocality surrounding exploratory tasks (Daft and Lengel 1986; Lubatkin et al. 2006, p. 648). At the same time, increasing levels of density within a network increases trust and cooperation and decreases the likelihood of goal conflict within the network (Adler and Kwon 2002, Rowley et al. 2000), which benefits the exploitation of new knowledge and the implementation of innovations (Jansen et al. 2005, Sheremata 2000).

These arguments suggest that connectedness is positively related to a manager's ambidextrous behavior. However, beyond a moderate level, increasing levels of a manager's connectedness may have dampening effects on that manager's ambidexterity. Increasingly dense networks diffuse strong norms, establish shared behavioral expectations, and create a dominant logic (Bettis and Wong 2003, Miller 1993, Rowley et al. 2000). First, this reduces managers' openness to different opportunities, needs, and perspectives (Nahapiet and Ghoshal 1998), which reduces their motivation and ability to host contradictions (Smith and Tushman 2005). Second, it constrains managers to perform broad searches for acquiring knowledge and information (Jansen et al. 2005), which reduces their ability to both refine and renew their knowledge base (Hansen et al. 2001, Sheremata 2000). Furthermore, a large and densely connected network may decrease managers' ability to engage in high levels of both exploration and exploitation related activities because maintaining such a network requires time and effort to stay in touch and interact with others (Hansen et al. 2001, Uzzi 1997). Hansen et al. (2001), for instance, show that maintaining a densely connected network is associated with reduced speed and efficiency in completing both explorative and exploitative projects. These arguments suggest the following hypothesis.

Hypothesis 4. There will be an inverted $U$-shaped relationship between connectedness of a manager to other organization members and this manager's ambidexterity.

\section{Interaction Effects Between Formal Structural and Personal Coordination Mechanisms}

A Manager's Decision-Making Authority and Participation in Cross-Functional Interfaces. As argued above, increasing decision-making authority of managers positively relates to their ambidexterity by increasing their freedom and ability to actively pursue a range of diverse goals (Gibson and Birkinshaw 2004, O'Reilly and Tushman 2004). However, increasing freedom to actively pursue a range of diverse goals confronts managers with the challenge to reduce uncertainty and equivocality about which goals to pursue, about how to pursue a range of diverse goals, and about the possible outcomes of the goals being pursued (Floyd and Lane 2000, Smith and Tushman 2005). Participation in crossfunctional interfaces increases managers' opportunities and ability to reduce such uncertainty and equivocality (Daft and Lengel 1986, Miller 1987), for instance, by promoting thorough and multifaceted assessments of problems, proposals, and projects; by exchanging information, opinions, and judgments with experts; by eliciting factual arguments from managers who have to defend their proposals before peers; and by offering opportunities for consultation (Daft and Lengel 1986, Egelhoff 1991, Miller 1987).

Furthermore, as increasing decision-making authority of managers enables them to pursue a range of diverse goals (Gibson and Birkinshaw 2004, O'Reilly and Tushman 2004), authors indicate the importance for ambidextrous managers to deal with conflict. Pursuing multiple and different goals is associated with getting confronted with other managers who hold different expectations, who have different perspectives, and who pursue contrasting goals (Duncan 1976, p. 180; Floyd and Lane 2000, p. 162; Smith and Tushman 2005 , p. 525). Participation in cross-functional interfaces increases managers' ability to effectively confront and resolve conflicts with other managers in several waysfor example, by stimulating discussion and cooperation among them (Duncan 1976, p. 181), by stimulating trust among them (Adler et al. 1999, p. 52), and by motivating systematic attempts to scrutinize and reconcile divergent perspectives (Miller 1987, p. 11).

Finally, increasing decision-making authority of managers positively relates to their ambidexterity by increasing their motivation to use and refine their existing skills and expertise as well as to develop new skills and expertise (Crossan and Berdrow 2003, McGrath 
2001, Floyd and Lane 2000). Participation in crossfunctional interfaces increases managers' opportunities to do so by creating a context for managers with different backgrounds to learn from each other (Gibson and Birkinshaw 2004) and by offering opportunities to exchange knowledge which enables participants to acquire both new and diverse knowledge and related and complementary knowledge (Egelhoff 1991, Jansen et al. 2005). These arguments suggest the following hypothesis.

НYротнеSIS 5. There will be positive interaction effects between a manager's decision-making authority and participation in cross-functional interfaces by the manager, on this manager's ambidexterity.

A Manager's Decision-Making Authority and Connectedness. Increasing managers' decision-making authority positively relates to these managers' ambidexterity by stimulating their willingness to become aware and recognize a large diversity of organizational, market, and technological opportunities and needs (Pierce and Delbecq 1977, Sheremata 2000, Tushman and O'Reilly 1996). Increasing the size of managers' networks helps them to become more aware and recognize a larger diversity of such opportunities and needs, by creating more possibilities to search for and identify different ideas, information, and inputs from organization members across hierarchical levels and organizational units (Birkinshaw and Gibson 2004, Burt 1992, Jaworski and Kohli 1993).

Furthermore, increasing the decision-making authority of managers positively relates to their ambidexterity because it makes them more sensitive to thoroughly understanding the identified diverse needs and opportunities before acting upon them (Adler et al. 1999, Sheremata 2000). However, understanding ideas, information, and inputs from different units and levels in an organization may be difficult because they tend to develop different languages, world views, and thought worlds (Burns and Stalker 1961, Duncan 1976). Increasing connectedness of a manager to other organization members enhances this manager's ability to better understand and act upon the identified diverse needs and opportunities. This understanding can be improved through the ability of densely connected networks to reduce ambiguity surrounding different needs and opportunities by engaging into frequent, reciprocal, and nonroutine information processing (Daft and Lengel 1986, Egelhoff 1991).

Finally, as indicated by Hypothesis 4, increasingly dense networks may have dampening effects on managers' ambidexterity by diffusing strong norms and creating a dominant logic (Bettis and Wong 2003, Miller 1993, Rowley et al. 2000). This constrains managers to perform broad searches for knowledge and information (Jansen et al. 2005), and it reduces their openness to different opportunities, needs, and perspectives (Nahapiet and Ghoshal 1998). Increasing levels of managers' decision-making authority may, however, countervail these negative effects of densely connected networks (Sheremata 2000, p. 401). For instance, increasing decision-making authority stimulates managers to broaden their search for knowledge and information outside their current network of contacts (Jansen et al. 2005, p. 1001), leading to a richer network of diverse knowledge (Hage and Aiken 1967, p. 510). Related to this, others have indicated that increasing decision-making authority enlarges the diversity of managers' perspectives (Zmud 1982), increases variety in their experience (McGrath 2001), and enlarges the range of diverse solutions they find to problems (AtuaheneGima 2003). These arguments suggest the following hypothesis.

HyPOTHESIS 6. There will be positive interaction effects between a manager's decision-making authority and connectedness of the manager to other organization members, on this manager's ambidexterity.

Formalization of a Manager's Tasks and Participation in Cross-Functional Interfaces. Increasing formalization of managers' tasks negatively relates to their ambidexterity by fostering singleness of purpose and hence decreasing the range of different goals these managers are likely to pursue (Hage 1965, Pierce and Delbecq 1977). Participation in cross-functional interfaces may reduce these effects of formalization; it forces managers to increase the range of different goals to take into consideration (Miller 1987, Whetten 1978) because it demands that they cooperate with other managers who are likely to differ in terms of interests, perspectives, beliefs, and values (Duncan 1976).

Furthermore, increasing formalization of managers' tasks negatively relates to managers' ambidexterity because it increases their sense of isolation resulting in a reduced motivation of these managers to combine efforts with others (Hage and Aiken 1969, Organ and Greene 1981). The literature indicates, however, that participation in cross-functional interfaces pulls managers out of their isolation and increases their motivation to combine efforts with others. For instance, it positively influences motivation to work together to solve problems (Sheremata 2000), to implement innovations (Duncan 1976), and to generate mutual commitment to make and realize decisions (Bahrami and Evans 1987).

Finally, increasing formalization of managers' tasks negatively relates to these managers' ambidexterity by stimulating them to increasingly develop expertise within the specialized area of their formalized tasks (Hage 1965, Zander and Kogut 1995) and by making it more difficult for them to broaden their knowledge and skill base (Daft and Lengel 1986). Effective participation in cross-functional interfaces, however, requires managers to understand, enter into discussion, and interact with managers from different fields of expertise 
and with different knowledge (Egelhoff 1991, Ghoshal and Bartlett 1988). Consequently, participation in crossfunctional interfaces stimulates managers to learn from each other (Nonaka and Konno 1998); to broaden their expertise beyond the narrow confines of their own job (Bahrami and Evans 1987, Miller 1987); and to broaden their knowledge base by acquiring, assimilating, and using new knowledge (Jansen et al. 2005). These arguments suggest the following hypothesis.

Hypothesis 7. There will be positive interaction effects between formalization of a manager's tasks and participation in cross-functional interfaces by the manager, on this manager's ambidexterity.

Formalization of a Manager's Tasks and Connectedness. Increasing formalization of managers' tasks negatively relates to these managers' ambidexterity because formalization increases the possibility that a manager becomes less receptive to decision-making stimuli that are not monitored by formal systems (Cyert and March 1963). An increasing size of managers' networks across organization units and hierarchical levels may more than compensate for these effects of formalization by extending the number of information channels by which a manager can access valuable ideas, insights, and information (Burt 1992, Ghoshal et al. 1994). Furthermore, an increasingly dense network of personal contacts positively influences the speed by which these ideas, insights, and information become available to the network members (Burt 1992, Nahapiet and Ghoshal 1998).

Increasing formalization of managers' tasks negatively relates to their ambidexterity by reducing the extent to which these managers establish and maintain interpersonal relations (Hage and Aiken 1969, Pugh et al. 1963). Moreover, it may increase a sense of isolation, resulting in a reduced motivation to cooperate and combine efforts with others (Organ and Greene 1981, Pierce and Delbecq 1977). Increasing levels of connectedness with other organization members may compensate these effects because doing so is directly associated with establishing and maintaining an increasing number of interpersonal relations (Jaworksi and Kohli 1993). Furthermore, increasing levels of densely connected relations decreases the network members' sense of isolation and increases their motivation to cooperate and combine efforts by developing trust and mutual identification (Adler and Kwon 2002, Coleman 1990), by providing a common frame of reference (Coleman 1990, Uzzi 1997), and by reducing the probability of opportunistic behavior (Rindfleisch and Moorman 2001).

Finally, increasingly dense networks may have dampening effects on a manager's ambidexterity because maintaining a large and densely connected network requires time and effort which is associated with increased costs and reduced efficiency in performing tasks and with reduced speed in completing both explorative and exploitative projects (Hansen et al. 2001, Uzzi 1997). Increasing levels of formalization of managers' tasks may undo these negative effects of increasing levels of connectedness as increasing formalization of tasks is associated with higher production, greater efficiency in performance, and increased speed of decision making (Baum and Wally 2003, Hage 1965, Hall et al. 1967). These arguments suggest the following hypothesis.

HYPOTHESIS 8. There will be positive interaction effects between formalization of a manager's tasks and connectedness of the manager to other organization members, on this manager's ambidexterity.

\section{Methods}

\section{Sample and Data Collection}

We followed existing quantitative studies on managers' activities that typically draw upon a sample composed of a large number of managers of a small number of firms (e.g., Ghoshal et al. 1994, Ireland et al. 1987, Walsh 1988). To test the hypotheses, we obtained data through a survey of managers in five large firms. Each of these firms ranks among the top 25 on the Fortune Global 500 (2007) in terms of total revenues in their industry. The choice of these five companies was a result of several considerations. To minimize compromising the external validity of the findings due to industry specific effects, we selected firms that operate in different manufacturing and service industries (Gibson and Birkinshaw 2004): electronics (Firm A), financial services (Firm B), accountancy and professional services (Firm C), telecommunications (Firm D), and chemicals (Firm E). Furthermore, investigating managers' ambidexterity compelled us to examine managers whose firms are confronted with pressures to explore and with pressures to exploit. Several studies (e.g., Banker et al. 2005, Flier et al. 2001, Gibson and Birkinshaw 2004, Henisz and Macher 2004) indicate that firms in the selected industries are forced to explore due to changes regarding technologies, customer demands, competition, and regulation. These studies also indicate that these firms are forced at the same time to exploit due to short-term competitive pressures in terms of an increased focus on efficiency and cutting costs and the increasing importance of economies of scale. Moreover, focusing on large firms increased the possibility to observe variance not only in this study's dependent variable but also in the explanatory variables (Ghoshal et al. 1994, McDonough and Leifer 1983).

In each of the firms, the survey was sent, in consultation with corporate top management, to a number of selected managers. These are business unit level and operational level managers with various functional backgrounds such as research and development, marketing 
and sales, and operations. Furthermore, the managers represent a wide variety in terms of demographic characteristics such as age, job tenure, functional tenure, and education. The survey was sent to 1,797 managers. For each firm, chi-square tests $(p<0.05 ; \alpha=0.05)$ indicate that the distribution of the managers over the hierarchical levels and functional areas corresponds to the distribution of all managers. This indicates that bias due to the sampling procedure may not be a problem. To ensure confidentiality, we agreed not to reveal the names of the respondents, who returned the completed surveys to us without interference from corporate management. We received 755 completed surveys, corresponding to a response rate of $42 \%$. List-wise deletion of cases with missing values reduced the final sample size to $716 ;^{1}$ i.e. 110, 161, 186, 148, and 111 managers of Firm A, B, $\mathrm{C}, \mathrm{D}$, and E, respectively. This sample included 215 business unit level managers and 501 operational level managers. The average age of the managers is 39 years, the average job tenure within the firm is 10 years, and the average span of control is 41 employees.

We examined differences between respondents and nonrespondents to test for nonresponse bias. Chi-square tests $(p<0.05 ; \alpha=0.05)$ indicate that the distribution of the respondents over the firms, hierarchical levels, and functions corresponds to the population's distribution. We also compared early and late respondents ( $t$-test; $p<$ $0.05)$ in terms of demographic characteristics and model variables because late respondents can be expected to be similar to nonrespondents (Armstrong and Overton 1977). No significant differences appeared, indicating that nonresponse bias may not be a problem.

\section{Measures and Validation}

Dependent Variable. We constructed a scale to measure a manager's ambidexterity beccuase an appropriate scale at the individual level was not available in the literature. Scales of firm or business unit ambidexterity are constructed by combining measures of exploration and exploitation (Gibson and Birkinshaw 2004, He and Wong 2004, Lubatkin et al. 2006). Following this practice, we started by developing measures for exploration and exploitation at the manager level of analysis.

To develop these measures, we took the following steps. First, following the definition of ambidexterity at the manager level, we developed seven manager's exploration activity items and seven manager's exploitation activity items. To enhance content validity, we developed these items based on the features by which March (1991, p. 71) characterized the constructs of exploration and exploitation and based on studies that illustrate managers' ambidextrous behavior in terms of exploration and exploitation related activities (e.g., Adler et al. 1999, Floyd and Lane 2000, Ghemawat and Ricart I Costa
1993, Tushman and O'Reilly 1996). Second, to further increase content validity and to enhance the wording of the items, six in-depth interviews were held by the authors with managers of various hierarchical and functional positions of firms A, B, and C. During the interviews, managers were asked to complete the questionnaire, to indicate the relevance of the items, and to indicate any ambiguity regarding the phrasing of the items. Based on these interviews, the content and phrasing of the items were further enhanced by the authors, a process which resulted in a test version of the survey. Third, to allow enhancement of the reliability, unidimensionality, and convergent and discriminant validity of the exploration and exploitation scales, we quantitatively tested the scales based on data we obtained through a test version of the survey of 33 managers of various hierarchical and functional positions of firms A, B, and C. Following reliability and validity analyses, five ambiguous items of the exploration and exploitation scales were identified. Fourth, during 12 in-depth interviews with managers of various hierarchical and functional positions of firms $\mathrm{A}, \mathrm{B}$, and $\mathrm{C}$, managers were asked to suggest improvements to the ambiguous items as identified at the previous step. Based on these interviews, we further enhanced the phrasing of these items, a process that resulted in the final version of the scales. The exploration scale determines the extent to which a manager engaged in exploration activities last year, whereas the exploitation scale determines the extent to which the manager engaged in exploitation activities last year.

To check for convergent and discriminant validity, we performed exploratory and confirmatory factor analyses. Exploratory factor analysis (see Table 1) with Varimax rotation with all 14 items, based on the survey data, revealed that two summated scales could be constructed; one exploration scale with the seven exploration items and one exploitation scale with the seven exploitation items. Eigenvalues for each factor were greater than 3.6, all items loaded on their appropriate factors at greater than 0.69, and no item cross-loading was greater than 0.18 . Both scales are reliable: exploration $\alpha=0.90$; exploitation $\alpha=0.87$. We conducted confirmatory factor analysis (CFA) of the 14 items to check for discriminant validity of the constructs. Results indicate that the twofactor model fits the data well $(\mathrm{NFI}=0.93, \mathrm{CFI}=0.95$, RMSEA < 0.07). Moreover, a comparison of a onefactor model with a two-factor model shows a significant improvement in fit $\left(\Delta \chi^{2}\right.$ significant at $\left.p<0.001\right)$, providing evidence of discriminant validity (Bagozzi and Phillips 1982).

Prior studies combine exploration and exploitation measures to assess ambidexterity (Gibson and Birkinshaw 2004, He and Wong 2004, Lubatkin et al. 2006). Gibson and Birkinshaw's (2004, p. 211) conceptualization of ambidexterity explicitly takes the ambidextrous behavior of individuals into consideration. In our 
Table 1 Factor Analysis for Managers' Ambidexterity

\begin{tabular}{|c|c|c|}
\hline & & $\mathrm{prs}^{\mathrm{b}}$ \\
\hline \multicolumn{3}{|l|}{ Items ${ }^{a}$} \\
\hline $\begin{array}{l}\text { To what extent did you, last year, engage } \\
\text { in work related activities that can be } \\
\text { characterized as follows: }\end{array}$ & 1 & 2 \\
\hline \multicolumn{3}{|l|}{ A manager's exploration activities $(\alpha=0.90)$} \\
\hline $\begin{array}{l}\text { Searching for new possibilities with } \\
\text { respect to products/services, } \\
\text { processes, or markets }\end{array}$ & 0.82 & -0.05 \\
\hline $\begin{array}{l}\text { Evaluating diverse options with respect to } \\
\text { products/services, processes, or } \\
\text { markets }\end{array}$ & 0.84 & -0.05 \\
\hline $\begin{array}{l}\text { Focusing on strong renewal of } \\
\text { products/services or processes }\end{array}$ & 0.79 & -0.02 \\
\hline $\begin{array}{l}\text { Activities of which the associated yields or } \\
\text { costs are currently unclear }\end{array}$ & 0.74 & -0.05 \\
\hline $\begin{array}{l}\text { Activities requiring quite some adaptability } \\
\text { of you }\end{array}$ & 0.83 & \\
\hline $\begin{array}{l}\text { Activities requiring you to learn new skills } \\
\text { or knowledge }\end{array}$ & 0.76 & -0.06 \\
\hline $\begin{array}{l}\text { Activities that are not (yet) clearly existing } \\
\text { company policy }\end{array}$ & 0.72 & -0.13 \\
\hline \multicolumn{3}{|l|}{ A manager's exploitation activities ( $\alpha=0.87)$} \\
\hline $\begin{array}{l}\text { Activities of which a lot of experience has } \\
\text { been accumulated by yourself }\end{array}$ & 0.08 & \\
\hline $\begin{array}{l}\text { Activities which you carry out as if it were } \\
\text { routine }\end{array}$ & -0.18 & \\
\hline $\begin{array}{l}\text { Activities which serve existing (internal) } \\
\text { customers with existing } \\
\text { services/products }\end{array}$ & -0.08 & \\
\hline $\begin{array}{l}\text { Activities of which it is clear to you how to } \\
\text { conduct them }\end{array}$ & -0.11 & 0.80 \\
\hline $\begin{array}{l}\text { Activities primarily focused on achieving } \\
\text { short-term goals }\end{array}$ & -0.03 & \\
\hline $\begin{array}{l}\text { Activities which you can properly conduct } \\
\text { by using your present knowledge }\end{array}$ & -0.03 & \\
\hline $\begin{array}{l}\text { Activities which clearly fit into existing } \\
\text { company policy }\end{array}$ & 0.00 & 0.75 \\
\hline
\end{tabular}

altems are quoted from our survey. All items were measured on a seven-point scale $(1=$ to a very small extent to $7=$ to a very large extent).

${ }^{\mathrm{b}}$ Extraction method: principal component analysis. Rotation method: Varimax with Kaiser normalization. Explained variance: $60 \%$.

study on individual level ambidexterity, we followed their approach by assessing managers' ambidexterity by computing the multiplicative interaction between managers' exploration activities and managers' exploitation activities.

Independent Variables. This study's measures of the formal structural and personal coordination mechanisms are based on existing scales. To measure the extent of a manager's decision-making authority, we used a four item scale of Dewar et al. (1980), which assesses the extent to which a manager has decision-making authority in the performance of his or her tasks and in his or her ability to set goals $(\alpha=0.91)$. To assess the extent of formalization of a manager's tasks, this study used a four item scale from Desphande and Zaltman (1982), which measures the extent to which a manager's tasks are defined by rules, procedures, or regulations $(\alpha=0.89)$. To measure participation in cross-functional interfaces by a manager, this study used a scale on the basis of Nadler and Tushman (1987) and Gupta and Govindarajan (2000), which assesses the extent to which a manager participates in cross-unit and crosshierarchical integrative mechanisms, asking each manager to what extent he or she (1) coordinates work across internal organizational boundaries, (2) works in temporary task forces, and (3) works in permanent teams. Following Gupta and Govindarajan (2000, p. 495) and Jansen et al. (2005, p. 1005), we constructed the final measure as a weighted average of the three items, where the first item is given a weight of 1 , the second item a weight of 2 , and the last item a weight of 3 . To measure connectedness of a manager to other organization members, a four-item scale based on Jaworski and Kohli (1993) and Jansen et al. (2006) was used, which assessed the extent to which a manager is networked or connected to other organization members across hierarchical levels and organizational units in terms of direct personal contacts $(\alpha=0.87)$. Prior to the creation of the interaction terms in the regression models, we mean centered the independent variables to reduce multicollinearity (Aiken and West 1991). Appendix 1 shows the items of the independent variables.

Control Variables. Managers' experience may influence their ambidexterity: increased levels of experience are associated with an increased ability to interpret and deal with a larger diversity of ambiguous cues (Daft and Lengel 1986, p. 555). The broadness of experience also matters because an ambidextrous manager's skill base is "more generalist" rather than "more specialist" (Birkinshaw and Gibson 2004, p. 49). To control for experience, we included a manager's age and tenure within the firm, which are expected to positively relate to managers' ambidexterity (Tushman and O'Reilly 1996, p. 27). We also included a manager's tenure in his or her current function, which is associated with increasing levels of specialization and hence is expected to negatively relate to the manager's ambidexterity (cf. Birkinshaw and Gibson 2004, p. 49). Increasing levels of education are associated with increasing cognitive abilities to process information and learning (Papadakis et al. 1998), which may positively relate to managers' ambidexterity (Adler et al. 1999, p. 51). We controlled for educational effects by including two dummy variables; one reflecting managers with master's degrees or higher, and another reflecting managers with bachelor's degrees, making managers with degrees below the bachelor's level the reference group. Exploration and exploitation compete for scarce resources (March 1991). Managers of larger 
units may have more resources at their disposal, which can be allocated to both exploration and exploitation activities (Lewin et al. 1999). To control for size effects, we included the natural $\log$ of the number of subordinates of a manager. The hierarchical level of a manager may impact upon the manager's level of ambidexterity. Higher level managers are typically expected to be more ambidextrous than lower level managers (Floyd and Lane 2000, p. 158; O'Reilly and Tushman 2004). We distinguished business unit level managers and operational level managers and controlled for hierarchical level effects by including one dummy variable (business unit level $=1$, operational level $=0$ ). Business unit level managers had at least two levels of supervisors under their responsibility and were no more than two reporting levels below top executives. Operational level managers report to business unit managers or to levels below these managers (cf. Ireland et al. 1987, p. 474). Levels of managers' exploration and exploitation activities may differ across functional areas (Duncan 1976). We created three dummy variables, one for research and development (R\&D), one for marketing and sales $(M \& S)$, and one for operations, to control for functional effects. Dummies for R\&D and M\&S are included in the regression models. Environmental dynamism may influence the extent to which a manager engages in exploration or exploitation activities or both (Jansen et al. 2006, Lewin et al. 1999). We therefore included a fouritem scale $(\alpha=0.89)$ that captured the degree of environmental dynamism that a manager faces (Dill 1958, Jansen et al. 2006). Sample items are "My (internal or external) clients regularly ask for complete new products and services" and "In my business, changes are intense." Finally, to control for organizational contextual factors (Gibson and Birkinshaw 2004), we created dummy variables reflecting the five firms. No dummy has been included for Firm E, making this firm the reference firm.

Validation. We conducted exploratory and confirmatory factor analyses including all items of this study's constructs, i.e., those measuring exploration, exploitation, and the four coordination mechanisms, to assess construct validity of the measures. Results of the exploratory factor analysis (extraction method: principal component analysis; rotation method: Varimax with Kaiser normalization) indicate that the measures were appropriately constructed; eigenvalues for each factor were greater than one, all items loaded on their appropriate factors at greater than 0.67 , and no item crossloading was greater than 30, supporting the six-factor solution. We conducted an integrated confirmatory factor analysis on all items. We allowed each item to load only on the factor for which it was a proposed indicator. Results indicate that the six-factor model fits the data well $(\mathrm{NFI}=0.92, \mathrm{CFI}=0.95, \mathrm{RMSEA}<0.05)$. Moreover, a comparison of a one-factor model with a twofactor model for every pair among the factors shows a significant improvement in fit for each of the 15 pairs ( $\Delta \chi^{2}$ significant at $\left.p<0.001\right)$, providing evidence of discriminant validity (Bagozzi and Phillips 1982).

\section{Analysis and Results}

Table 2 shows descriptive statistics and correlations for all variables. Table 3 presents the results of the hierarchical regression analyses for managers' ambidexterity. To examine multicollinearity, we calculated the variance inflation factor (VIF) for each of the regression equations. VIFs are between 3.48 and 1.08 , which is below the rule-of-thumb cutoff of 10 (Neter et al. 1990); issues of multicollinearity seem not to be a problem. Among the control variables, the full model-Model 3 of Table 3-shows that age and tenure in the current function negatively relate to managers' ambidexterity, that tenure in the firm and environmental dynamism positively relate to managers' ambidexterity, that business unit level managers are more ambidextrous than operational level managers, and that managers of Firm A are more ambidextrous than those of the reference Firm, whereas managers of Firm D are less ambidextrous.

Tests of Main Effects. Model 2 of Table 3 shows the main effects referring to Hypotheses 1-4. This model shows that a manager's decision-making authority positively relates to this manager's ambidexterity $(\beta=0.14$, $p<0.001$ ), supporting Hypothesis 1 . The coefficient for formalization of a manager's tasks is positive and not significant $(\beta=0.03, \mathrm{~ns})$; hence, Hypothesis 2 is not supported. Participation of a manager in cross-functional interfaces positively relates to the manager's ambidexterity $(\beta=0.19, p<0.001)$, supporting Hypothesis 3 . Regarding connectedness of a manager to other organization members, we predicted an inverted U-shaped relationship with this manager's ambidexterity. As Model 2 shows, the coefficient for connectedness is positive and significant $(\beta=0.17, p<0.001)$. However, the coefficient for the squared term is positive and not significant $(\beta=0.03$, ns). Accordingly, the relationship between a manager's connectedness to other organization members and the manager's ambidexterity is positive rather than curvilinear, thereby not supporting Hypothesis 4 . Regarding the size of the three significant main effects, two significant differences appear. That is, the coefficient of participation in cross-functional interfaces is larger than the coefficient of decision-making authority ( $t$-value of difference $=2.47 ; p<0.05 ; 2$-tailed testing), and the coefficient of connectedness is larger than the coefficient of decision-making authority ( $t$-value of difference $=$ 1.94; $p<0.05$; two-tailed testing). Hence, the direct effect of the two personal coordination mechanisms on 


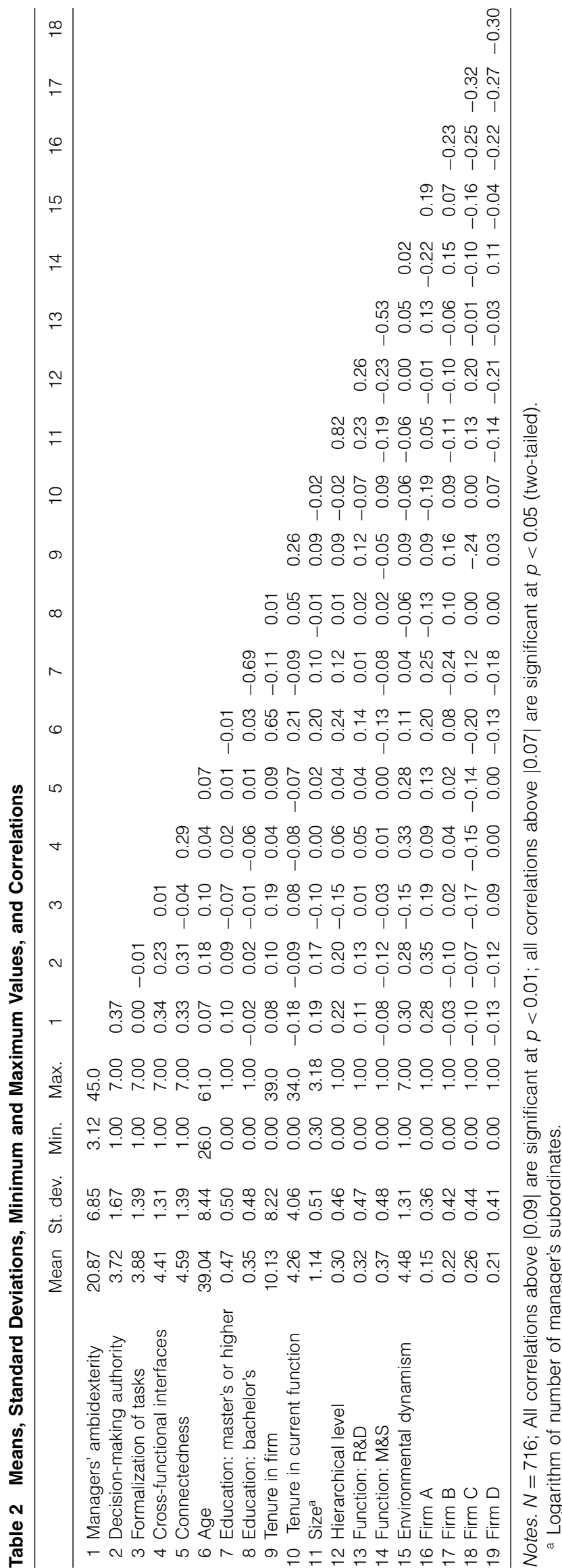

managers' ambidexterity is larger than the direct effect of the formal structural coordination mechanisms.

Tests of Interaction Effects. Model 3 of Table 3 shows the interaction effects referring to Hypotheses 5-8. As the inclusion of connectedness squared did not significantly improve model fit (Model 2 of Table 3), we dropped the squared term in Model 3 (e.g. Katila and Ahuja 2002). The interaction term between a manager's decision-making authority and participation in crossfunctional interfaces by the manager is positive and significant $(\beta=0.12, p<0.001)$, supporting Hypothesis 5. Hypothesis 6 is also supported because the interaction term between a manager's decision-making authority and the manager's connectedness to other organization members is positive and significant $(\beta=0.09$, $p<0.01)$. The interaction term between formalization of a manager's tasks and the manager's participation in cross-functional interfaces is positive and significant ( $\beta=0.09, p<0.01)$, supporting Hypothesis 7 . Hypothesis 8 is also supported because the interaction term between formalization of a manager's tasks and the manager's connectedness to other organization members is positive and significant $(\beta=0.11, p<0.01)$. These results indicate that positive interaction effects exist between the formal structural and the personal coordination mechanisms on managers' ambidexterity. There are no significant differences between the four interaction effects in terms of their size.

Post Hoc Analyses. The sample's managers can be grouped into different functional areas, firms, and hierarchical levels. We conducted several post hoc analyses, which indicate that (1) possible functional area, firm, or hierarchical level specific characteristics are not driving the results of the paper as presented in Table 3 and (2) the results as reported in Table 3 do not significantly differ across functional area, firm, or hierarchical level subgroups of managers. With respect to the second result, there are two exceptions: the effect of decision-making authority on ambidexterity is larger for operational level managers than for business unit level managers, whereas the effect of participation in crossfunctional interfaces on ambidexterity is larger for business unit level managers than for operational level managers. For the detailed procedures and results of the post hoc analyses, refer to Appendix 2.

\section{Discussion and Conclusion}

The current body of research on ambidexterity focuses on firm and business unit level ambidexterity. Although some scholars explicitly argue that "ambidextrous organizations need ambidextrous senior teams and managers" (O'Reilly and Tushman 2004, p. 81), conceptual and empirically validated understanding about what is 
Table 3 Results of Hierarchical Regression Analyses for a Manager's Ambidexterity

\begin{tabular}{|c|c|c|c|c|c|c|}
\hline & \multicolumn{2}{|c|}{ Model 1} & \multicolumn{2}{|c|}{ Model 2} & \multicolumn{2}{|c|}{ Model 3} \\
\hline & b (s.e.) & $\beta$ & b (s.e.) & $\beta$ & b (s.e.) & $\beta$ \\
\hline Intercept & $16.94(1.91)$ & & $19.57(1.84)$ & & $19.31(1.77)$ & \\
\hline \multicolumn{7}{|l|}{ Main effects } \\
\hline A manager's decision-making authority & & & $0.57(0.15)$ & $0.14^{* * *}$ & $0.52(0.15)$ & $0.13^{* * *}$ \\
\hline Formalization of a manager's tasks & & & $0.13(0.17)$ & 0.03 & $0.16(0.16)$ & 0.03 \\
\hline Part. in cross-functional interfaces by a manager & & & $1.01(0.18)$ & $0.19^{* * *}$ & $0.94(0.17)$ & $0.18^{* * *}$ \\
\hline Connectedness of a manager to other org. members & & & $0.85(0.18)$ & $0.17^{* * *}$ & $0.83(0.16)$ & $0.17^{* * *}$ \\
\hline Connectedness-squared & & & $0.09(0.10)$ & 0.03 & & \\
\hline \multicolumn{7}{|l|}{ Interaction effects } \\
\hline Dec. making authority $*$ Cross-fun. interfaces & & & & & $0.36(0.10)$ & $0.12^{* * *}$ \\
\hline Dec. making authority $*$ Connectedness & & & & & $0.27(0.09)$ & $0.09^{* *}$ \\
\hline Formalization $*$ Cross-fun. interfaces & & & & & $0.31(0.11)$ & $0.09 * *$ \\
\hline Formalization $*$ Connectedness & & & & & $0.35(0.10)$ & $0.11^{* *}$ \\
\hline \multicolumn{7}{|l|}{ Control variables } \\
\hline Age & $-0.11(0.04)$ & $-0.14^{* *}$ & $-0.10(0.04)$ & $-0.13^{* *}$ & $-0.11(0.03)$ & $-0.13^{* *}$ \\
\hline Education: master's or higher & $0.89(0.69)$ & 0.07 & $0.84(0.65)$ & 0.06 & $0.83(0.63)$ & 0.06 \\
\hline Education: bachelor's & $0.98(0.68)$ & 0.07 & $0.81(0.64)$ & 0.06 & $0.85(0.62)$ & 0.06 \\
\hline Tenure in firm & $0.11(0.04)$ & $0.13^{* *}$ & $0.09(0.04)$ & $0.11^{*}$ & $0.08(0.04)$ & $0.09 *$ \\
\hline Tenure in current function & $-0.21(0.06)$ & $-0.13^{* * *}$ & $-0.17(0.06)$ & $-0.10^{* *}$ & $-0.16(0.05)$ & $-0.09^{* *}$ \\
\hline Size (log) & $0.28(0.78)$ & 0.02 & $0.53(0.73)$ & 0.04 & $0.49(0.71)$ & 0.04 \\
\hline Hierarchical level & $3.24(0.92)$ & $0.22^{* * *}$ & $2.29(0.87)$ & $0.15^{* *}$ & $2.30(0.83)$ & $0.15^{* *}$ \\
\hline Function: R\&D & $0.29(0.59)$ & 0.02 & $0.18(0.55)$ & 0.01 & $0.21(0.53)$ & 0.01 \\
\hline Function: M\&S & $0.41(0.58)$ & 0.03 & $0.29(0.54)$ & 0.02 & $0.49(0.52)$ & 0.03 \\
\hline Environmental dynamism & $1.31(0.18)$ & $0.25^{* * *}$ & $0.63(0.19)$ & $0.12^{* *}$ & $0.70(0.18)$ & $0.13^{* * *}$ \\
\hline Firm A & $3.53(0.87)$ & $0.19^{* * *}$ & $2.63(0.86)$ & $0.14^{* *}$ & $2.36(0.83)$ & $0.12^{* *}$ \\
\hline Firm B & $-0.28(0.79)$ & -0.02 & $-0.04(0.74)$ & 0.00 & $-0.21(0.71)$ & -0.01 \\
\hline Firm C & $-1.25(0.75)$ & $-0.08^{\dagger}$ & $-0.57(0.71)$ & -0.04 & $-0.55(0.68)$ & -0.04 \\
\hline Firm D & $-1.13(0.82)$ & -0.07 & $-1.00(0.77)$ & -0.06 & $-1.29(0.74)$ & $-0.08^{\dagger}$ \\
\hline$R$-squared & & 0.23 & & 0.33 & & 0.38 \\
\hline Adjusted $R$-squared & & 0.21 & & 0.31 & & 0.36 \\
\hline$F$ improvement of fit & & $14.64^{* * *}$ & & $20.51^{* * *}$ & & $14.97^{* * *}$ \\
\hline
\end{tabular}

Notes. Centered data; Unstandardized coefficients are reported, with standard errors in parentheses, as well as standardized coefficients; $N=716 ;{ }^{\dagger} p<0.10 ;{ }^{*} p<0.05 ;{ }^{* *} p<0.01 ;{ }^{* * *} p<0.001$

ambidexterity at the manager level of analysis, and about variation in managers' ambidexterity, is still underdeveloped (Gupta et al. 2006, Raisch and Birkinshaw 2008). This paper contributed to further understanding on both issues in three ways: (1) by proposing and clarifying three related characteristics of ambidextrous managers by integrating insights from prior research; (2) by developing a model and associated hypotheses on both the direct and interaction effects of formal structural and personal coordination mechanisms on managers' ambidexterity; and (3) by testing the hypotheses based on a sample of 716 business unit level and operational level managers. The paper's contributions raise several important issues for both theory and practice.

First, whether ambidextrous managers may exist, i.e., whether exploration and exploitation exclude each other at the individual level of analysis, is still debated (cf. Gupta et al. 2006). Although it may be argued to be "very difficult for an individual to...excel at both exploration and exploitation" (Gupta et al. 2006, p. 696), this paper demonstrates that these difficulties are not insurmountable. By integrating insights from previous studies, we theorized and illustrated three related characteristics of ambidextrous managers. Empirically, the paper also demonstrates that managers can indeed be ambidextrous; i.e., they may engage in high levels of both exploration and exploitation related activities. This is, for instance, illustrated by the results of the exploratory and confirmatory factor analyses which show that exploration and exploitation are two distinct latent factors of a second order construct; managers' ambidexterity. This indicates that managers' exploration and exploitation activities are not mutually exclusive ends of a continuum. Furthermore, as the data indicates, managers differ in the extent to which they are ambidextrous. Whereas some are not ambidextrous because they focus on either exploration or exploitation, others are ambidextrous because they engage in high levels of both exploration and exploitation related activities.

Second, the paper furthers theoretical and empirically validated understanding about variation in managers' ambidexterity by developing and testing hypotheses on the direct effects of formal structural and personal coordination mechanisms on managers' ambidexterity. Existing 
studies on firm or business unit level ambidexterity mostly put forward structural mechanisms for advancing ambidexterity (e.g., Benner and Tushman 2003, Duncan 1976), whereas others have illustrated the importance of more personal relationships (e.g., Birkinshaw and Gibson 2004, Subramaniam and Youndt 2005). Regarding individual level ambidexterity, the hypotheses of this paper indicate that both kinds of mechanisms matter for managers' ambidexterity. However, empirical findings on the direct effects indicate that both types might not be equally effective. Instead, the findings emphasize the relatively large effect of the personal types of coordination mechanisms as compared to the formal structural types of mechanisms on managers' ambidexterity. This is in line with recent studies on learning and coordination that indicate the importance of more informal and personal types of coordination for shaping knowledge and learning related processes and activities of organization members (e.g., Argote et al. 2003, Faraj and Xiao 2006).

Interestingly, two hypotheses on the direct effects were not confirmed. With regard to formalization of a manager's tasks (Hypothesis 2), our findings did not provide support for the predicted negative relation with a manager's ambidexterity. This may concur with recent insights that suggest that formalized routines may increase information flows to managers, which may improve their overall quality and speed of decision making (Baum and Wally 2003). Formalized rules and procedures may also include processes for effecting change (Adler and Borys 1996), which corresponds to the Adler et al. (1999, p. 45) concept of "metaroutines" that may enable organizations to become more ambidextrous by transforming nonroutine tasks into more-routine ones. As the effect of formalization on individuals' behavior may be contingent on its design, future studies could differentiate between types of formalization, such as enabling and coercive types (Adler and Borys 1996). Regarding connectedness of a manager to other organization members across hierarchical levels and organization units, Hypothesis 4 predicted an inverted U-shaped relationship with this manager's ambidexterity. Instead, we found the relationship to be positive rather than curvilinear. Apparently, the expected dampening effects of increasing levels of connectedness on managers' ambidexterity are not present in the data sample. A possible explanation may be the study's research context of large firms in which members of organization units may differ considerably from each other in terms of values, norms, and their knowledge base, due to different products or services they provide, different technologies or processes they apply, and different markets they serve. Hence, future research may examine the impact of other characteristics of managers' personal networks such as the level of heterogeneity, which may make the diffusion of strong norms and the creation of a dominant logic more difficult, even if the network is densely connected (Reagans and Zuckerman 2001, Rodan and Galunic 2004, Smith et al. 2005).
Third, the paper develops theoretical and empirically validated understanding about variation in managers' ambidexterity by developing and testing hypotheses on the interaction effects of formal structural and personal coordination mechanisms on managers' ambidexterity. Not only empirically validated insight but also theoretical insight on the combined effect of different organizational elements on ambidexterity is scarce in the literature on ambidexterity (see, e.g., Jansen et al. 2006, Rivkin and Siggelkow 2003). This gap is highlighted by Raisch and Birkinshaw (2008, p. 399), who argue that "the interrelations between different antecedents" have thus far "been neglected or not been fully conceptualized in the literature on ambidexterity." Consequently, they argue to "develop and test propositions on how different antecedents interact and complement one another in a firm's pursuit of organizational ambidexterity" (Raisch and Birkinshaw 2008, p. 399). This paper's interaction hypotheses and the associated results indicate positive interaction effects between the formal structural and the personal coordination mechanisms. Hence, an interesting finding, also for managerial practice, is that the combined effect of the two types of coordination mechanisms on managers' ambidexterity is larger than simply the sum of their independent effects. In other words, complementing formal structural coordination mechanisms with personal mechanisms increases the mechanisms' contribution to managers' ambidexterity.

The paper's hypotheses and empirical findings on the interaction effects seem also to provide new avenues for research on new organizational forms. A wellestablished stream in contingency theory has examined mechanistic versus organic forms, stressing internal fit and consistency between coordination mechanisms (Burns and Stalker 1961, Duncan 1976, Lawrence and Lorsch 1967). However, our results seem to support hybrid or simultaneous forms that combine the formal structure with strong cross-functional integration and internal networks. In these illogical designs, according to contingency theory, there is a coexistence of formal organization structure and horizontal ties. Managers responsible for ambidextrous forms can choose to compensate their formal mechanistic structure by encouraging decision-making authority, cross-functional interfaces, and connectedness among their managers. On the other hand, they can also seize upon the formalization devices to solidify and extend a more homogeneous orientation of their managers. This simultaneous expression of formal hierarchical structure and horizontal relationships fosters their managers' ambidexterity.

Fourth, results of the post hoc analysis indicate that the effect of decision-making authority on ambidexterity is larger for operational level manager than for business unit level managers, whereas the effect of participation in cross-functional interfaces on ambidexterity is larger for business unit level managers than for operational level managers. These findings highlight the particular 
importance, also for managerial practice, of personal coordination mechanisms for business unit level managers' ambidexterity. This is in line with studies on strategy process research, which indicate that business unit level managers focus on establishing interactions and building relationships between different hierarchical levels, organization units, and functions, for conducting exploration and exploitation related activities (Burgelman 1983, Floyd and Lane 2000). One of the main characteristics of cross-functional interfaces is that they allow for establishing interactions and building relationships across internal vertical, horizontal, and lateral organizational boundaries (Martinez and Jarillo 1989, Galbraith 1973). Therefore, cross-functional interfaces may have greater capacity for enabling business unit level managers' ambidexterity as compared to operational level managers' ambidexterity. An interesting finding, also for managerial practice, is the importance of formal structural coordination mechanisms for operational level managers' ambidexterity. This is in line with, among others, Floyd and Lane (2000), who stress the importance of formal structural mechanisms for shaping lower level managers' exploration and exploitation activities.

Finally, investigating ambidexterity at the manager level of analysis raises the question about the locus of action, i.e., about who exerts control on the coordination mechanisms to enable managers' ambidexterity. Several studies on ambidexterity at the firm and business unit level of analysis indicate the importance of corporate or most senior management for controlling formal structural elements (e.g., Duncan 1976, Tushman and O'Reilly 1996) and for developing the organization context (Gibson and Birkinshaw 2004, p. 223). Investigating ambidexterity at the manager level of analysis highlights an important insight for managerial practice: the importance of both these managers' supervisors, which may reside at lower levels in the organization than corporate management, and the managers themselves for shaping these managers' surroundings, and, consequently, their ambidexterity. We argue that regarding a manager's decision-making authority and formalization of tasks, and to a large extent participation in cross-functional interfaces, the locus of action is most likely with that manager's direct supervisor and that manager's supervisors at higher levels. With regard to the connectedness of a manager to other organization members, the locus of action may be more with the manager him- or herself, as connectedness comprises a more "voluntary and personal mode of coordination" (Tsai 2002, p. 181). These arguments are in line with, for instance, McDonough and Leifer (1983), who argue and empirically demonstrate that a "supervisor may employ different structures at the same time for use by different individuals or groups within the work unit" (1983, p. 728).

\section{Limitations and Future Research}

Our study has limitations, suggesting several issues for future research. The study involves cross-sectional, single informant data and uses perceptual scales highlighting issues of common method bias and causal reciprocity. Regarding the issue of common method bias, we performed Harman's one-factor test on items included in the regression models. If common method bias were a serious problem in the study, we would expect a single factor to emerge to account for most of the covariance in the dependent and independent variables (Podsakoff and Organ 1986). We did not find such a single factor. The issue of common method bias could be addressed in future studies by measuring ambidexterity at the managerial level of analysis using objective measures. Furthermore, as indicated, our methods are suited to establish relationships between the constructs, but not causality. To create more insight in the direction of causality, future studies may adopt a longitudinal approach to increase insight into how changes in coordination mechanisms and changes in managers' ambidexterity causally relate to each other. Related to the question of causality is the discussion above on the locus of action. Future research could create more insight into this issue by adopting a multiple level approach examining interactions between actions and decisions of managers of different hierarchical levels. Furthermore, we limited the focus of this paper by investigating how different coordination mechanisms relate to the ambidextrous behavior of managers. Although this leads to valuable and actionable knowledge, future research could investigate other potential factors that relate to managers' ambidexterity. For instance, the results on the control variables indicate that demographic factors such as age, tenure in the firm, and tenure in the current function significantly relate to managers' ambidexterity. Future research could delve into the role of moderators, such as the hierarchical level of managers. Another limitation of this paper in this respect is that we did not explicitly address external drivers of managers' ambidexterity, except that we controlled for the impact of environmental dynamism. Hence, future research could explore and compare, for instance, the impact on managers' ambidexterity of formal inter-organizational personal relationships, like task forces with suppliers or clients, and more informal direct contacts with these external constituencies. Finally, in the introduction section of the paper, we illustrated that previous research indicates the relevance of investigating managers' ambidexterity for increasing understanding about how to build ambidexterity in a firm. In a related vein, it is also interesting to explicitly examine the relationships between managers' ambidextrous behavior and the firm's or business unit's level of ambidexterity and performance.

Despite these limitations, in response to the call for research into variations in managers' ambidexterity, this paper contributed to the literature by investigating, both 
conceptually and empirically, ambidexterity at the manager level of analysis and how different types of coordination mechanisms relate to variations in managers' ambidexterity. By doing so, we contributed to both theoretical and empirical foundations of the concept of ambidextrous organizations and their managers.

\section{Acknowledgments}

The authors thank Senior Editor Michael Tushman and Organization Science anonymous reviewers for their valuable comments. Suggestions from Woody Van Olffen, Jatinder Sidhu, Ernst Verwaal, Raymond Van Wijk, and Ed Zajac were helpful for improving earlier versions of this manuscript.

\section{Appendix 1. Measures and Items of Explanatory Variables at the Manager Level ${ }^{2}$}

A manager's decision-making authority (based on Dewar et al. 1980)

I can undertake little action until my supervisor approves a decision.

If I want to make my own decisions, I will be quickly discouraged.

I have to ask my supervisor before I do almost everything.

Any decision I make has to have my supervisor's approval.

Formalization of a manager's tasks (based on Desphande and Zaltman 1982)

Whatever situation arises, I have procedures to follow in dealing with it.

I have to follow strict operational procedures at all times.

Rules occupy a central place in my work related activities.

There is a written job description for going about my tasks.

Participation in cross-functional interfaces by a manager (based on Gupta and Govindarajan 2000, Nadler and Tushman 1987)

I coordinate work across internal organizational boundaries.

I work in temporary task forces.

I work in permanent teams.

Connectedness of a manager to other organization members (based on Jaworski and Kohli 1993)

There are many opportunities for me to talk to individuals from all kinds of different organizational units.

I very frequently have contact with people, regardless of rank or position.

The personal network I have throughout the organization can be called "extensive."

I feel very comfortable calling others, regardless of rank, position, or organizational unit, when the need arises.

\section{Appendix 2. Post Hoc Analyses}

The sample's managers can be grouped into different functional areas, firms, and hierarchical levels. We investigated whether possible functional area, firm, and hierarchical level specific characteristics are driving the results and whether the results differ across functional area, firm, and hierarchical level subgroups of managers. To do so, we first examined whether significant interaction effects exist between the four independent variables and functional area, firm, and hierarchical level, on managers' ambidexterity. Second, we examined whether the main effects that were found to be significant in Model 3 of Table 3 remain significant after including the functional area, firm, and hierarchical level interaction terms. Finally, we split the total sample into functional area, firm, and hierarchical level subgroups of managers to examine the main effects within each separate subgroup (Aiken and West 1991, Hardy 1993, Jaccard and Turrisi 2003).

After having created interaction terms of the dummy variables pertaining to the functional areas with the four independent variables, we included these interaction terms in regression Model 3 of Table 3. Results are as follows: First, the interaction terms are not significant, and including the interaction terms does not result in a significant improvement of model fit. Second, the three main effects that are found to be significant in Model 3 of Table 3 remain significant, whereas the main effect of formalization of tasks remains insignificant. Finally, the four main effects in each of the three functional area subsamples are the same as those in the total sample; i.e., within each of the three functional area subsamples there is no significant relation between formalization of tasks and managers' ambidexterity, but there are positive and significant relations between decision-making authority, participation in cross-functional interfaces, and connectedness, on managers' ambidexterity. These results indicate that functional area does not moderate the relation between the independent variables and managers' ambidexterity, that possible functional area specific characteristics are not driving the results as presented in Model 3 of Table 3, and that the results as presented in Model 3 of Table 3 do not differ across functional area subgroups.

After having created interaction terms of the dummy variables pertaining to the firms with the four independent variables, we included these interaction terms in regression Model 3 of Table 3. Results are the same as those for functional area: First, the interaction terms are not significant, and there is no significant improvement of model fit. Second, the three main effects that are found to be significant in Model 3 of Table 3 remain significant, whereas the main effect of formalization of tasks remains insignificant. Finally, the four main effects in each of the five firm subsamples are the same as those in the total sample. These results indicate that firm specific characteristics do not moderate the relation between the independent variables and managers' ambidexterity, that possible firm specific characteristics are not driving the results as presented in Model 3 of Table 3, and that the results as presented in Model 3 of Table 3 do not differ across firms.

After having created interaction terms of the dummy variables pertaining to the hierarchical levels with the four independent variables, we included these interaction terms in regression Model 3 of Table 3. Including these interaction terms, first, results in a significant improvement of model fit. More specifically, results indicate that the effect of decisionmaking authority on ambidexterity is larger for operational level manager than for business unit level managers, whereas the effect of participation in cross-functional interfaces on ambidexterity is larger for business unit level managers than for operational level managers. Second, notwithstanding these significant interaction effects, the three main effects that are found to be significant in Model 3 of Table 3 remain significant after inclusion of the interaction terms, whereas the main effect of formalization of tasks remains insignificant. Finally, the four main effects in both hierarchical level subsamples are the same as those in the total sample, except the effect of managers' decision-making authority, which is positive but not significant in the business unit level subsample. These 
results indicate that hierarchical level does moderate the relation between two of the independent variables and managers' ambidexterity but that possible hierarchical level specific characteristics are not driving the results as presented in Model 3 of Table 3.

\section{Endnotes}

${ }^{1}$ We identified two cases with residual values larger than three standard deviations (Aiken and West 1991). Excluding these two outliers did not change any of the results.

${ }^{2}$ All items were measured on a seven-point scale $(1=$ "to a very small extent" or "strongly disagree" to $7=$ "to a very large extent" or "strongly agree").

\section{References}

Adler, P. S., B. Borys. 1996. Two types of bureaucracy: Enabling and coercive. Admin. Sci. Quart. 41 61-89.

Adler, P. S., S. W. Kwon. 2002. Social capital: Prospects for a new concept. Acad. Management Rev. 27 17-40.

Adler, P. S., B. Goldoftas, D. Levine. 1999. Flexibility versus efficiency? A case study of model changeovers in the Toyota production system. Organ. Sci. 10 43-68.

Aiken, L. S., S. G. West. 1991. Multiple Regression: Testing and Interpreting Interactions. Sage, Newbury Park, CA.

Argote, L., B. McEvily, R. Reagans. 2003. Managing knowledge in organizations: An integrative framework and review of emerging themes. Management Sci. 49 571-582.

Armstrong, J. S., T. S. Overton. 1977. Estimating nonresponse bias in mail surveys. J. Marketing Res. 14 396-402.

Atuahene-Gima, K. 2003. The effects of centrifugal and centripetal forces on product development speed and quality: How does problem solving matter? Acad. Management J. 46 359-373.

Bagozzi, R. P., L. W. Phillips. 1982. Representing and testing organizational theories: A holistic construct. Admin. Sci. Quart. 27 459-489.

Bahrami, H., S. Evans. 1987. Stratocracy in high-technology firms. California Management Rev. 30 51-66.

Banker, R. D., H. Chang, R. Natarajan. 2005. Productivity change, technical progress, and relative efficiency change in the public accounting industry. Management Sci. 51 291-304.

Baum, J. R., S. Wally. 2003. Strategic decision speed and firm performance. Strategic Management J. 24 1107-1129.

Benner, M. J., M. L. Tushman. 2003. Exploitation, exploration, and process management: The productivity dilemma revisited. Acad. Management Rev. 28 238-256.

Bettis, R. A., S. S. Wong. 2003. Dominant logic, knowledge creation, and managerial choice. M. Easterby-Smith, M. A. Lyles, eds. Handbook of Organizational Learning \& Knowledge Management. Blackwell, Oxford, UK, 343-355.

Birkinshaw, J., C. Gibson. 2004. Building ambidexterity into an organization. MIT Sloan Management Rev. 45 47-55.

Burgelman, R. A. 1983. A process model of internal corporate venturing in the diversified major firm. Admin. Sci. Quart. 28 223-244.

Burgelman, R. A. 2002. Strategy as vector and the inertia of coevolutionary lock-in. Admin. Sci. Quart. 47 325-357.

Burns, T., G. M. Stalker. 1961. The Management of Innovation. Tavistock, London.

Burt, R. S. 1992. Structural Holes: The Social Structure of Competition. Harvard University Press, Cambridge, MA.

Coleman, J. S. 1990. Foundations of Social Theory. Harvard University Press, Cambridge, MA.

Cray, D. 1984. Control and coordination in multinational corporations. J. Internat. Bus. Stud. 15 85-98.

Crossan, M. M., I. Berdrow. 2003. Organizational learning and strategic renewal. Strategic Management J. 24 1087-1105.
Cyert, R. M., J. G. March. 1963. A Behavioral Theory of the Firm. Prentice-Hall, Englewood Cliffs, NJ.

Daft, R. L., R. H. Lengel. 1986. Organizational information requirements, media richness and structural design. Management Sci. 32 554-571.

Desphande, R., G. Zaltman. 1982. Factors affecting the use of market research information: A path analysis. J. Marketing Res. 19 $14-31$.

Dewar, R. D., D. A. Whetten, D. Boje. 1980. An examination of the reliability and validity of the Aiken and Hage scales on centralization, formalization, and task routines. Admin. Sci. Quart. 25 $120-128$.

Dill, W. R. 1958. Environments as an influence on managerial autonomy. Admin. Sci. Quart. 2 345-367.

Duncan, R. B. 1976. The ambidextrous organization: Designing dual structures for innovation. R. H. Kilmann, L. R. Pondy, D. Slevin, eds. The Management of Organization Design. North-Holland, New York, 167-188.

Egelhoff, W. G. 1991. Information-processing theory and the multinational enterprise. J. Internat. Bus. Stud. 22 341-368.

Faraj, S., Y. Xiao. 2006. Coordination in fast-response organizations. Management Sci. 52 1155-1169.

Flier, B., F. A. J. van den Bosch, H. W. Volberda, C. A. Carnevale, N. Tomkin, L. Melin, B. V. Quélin, M. P. Kriger. 2001. The changing landscape of the European financial services sector. Long Range Planning 34 179-207.

Floyd, S. W., P. J. Lane. 2000. Strategizing throughout the organization: Managing role conflict in strategic renewal. Acad. Management Rev. 25 154-177.

Galbraith, J. R. 1973. Designing Complex Organizations. AddisonWesley, Reading, MA.

Ghemawat, P., J. Ricart I Costa. 1993. The organizational tension between static and dynamic efficiency. Strategic Management $J$. 14 59-73.

Ghoshal, S., C. A. Bartlett. 1988. Creation, adoption, and diffusion of innovations by subsidiaries of multinational corporations. J. Internat. Bus. Stud. 19 365-388.

Ghoshal, S., H. Korine, G. Szulanski. 1994. Interunit communication in multinational corporations. Management Sci. 40 96-110.

Gibson, C. B., J. Birkinshaw. 2004. The antecedents, consequences, and mediating role of organizational ambidexterity. Acad. Management J. 47 209-226.

Gupta, A. K., V. Govindarajan. 2000. Knowledge flows within multinational corporations. Strategic Management J. 21 473-496.

Gupta, A. K., K. G. Smith, C. E. Shalley. 2006. The interplay between exploration and exploitation. Acad. Management J. 49 693-706.

Hage, J. 1965. An axiomatic theory of organizations. Admin. Sci. Quart. 10 289-320.

Hage, J., M. Aiken. 1967. Program change and organizational properties a comparative analysis. Amer. J. Sociol. 72 503-519.

Hage, J., M. Aiken. 1969. Routine technology, social structure, and organization goals. Admin. Sci. Quart. 14 366-376.

Hall, R. H., N. J. Johnson, J. E. Haas. 1967. Organizational size, complexity, and formalization. Amer. Sociol. Rev. 32 903-912.

Hansen, M. T., J. M. Podolny, J. Pfeffer. 2001. So many ties, so little time: A task contingency perspective on the value of social capital in organizations. Soc. Capital Organ. 18 21-57.

Hardy, M. A. 1993. Regression with dummy variables. Sage University Papers Series on Quantitative Applications in the Social Sciences, 07-093, Sage, Newbury Park, CA.

He, Z. L., P. K. Wong. 2004. Exploration vs. exploitation: An empirical test of the ambidexterity hypothesis. Organ. Sci. 15 481-494.

Henderson, R., I. Cockburn. 1994. Measuring competence? Exploring firm effects in pharmaceutical research. Strategic Management J. 15 63-84. 
Henisz, W. J., J. T. Macher. 2004. Firm- and country-level trade-offs and contingencies in the evaluation of foreign investment: The semiconductor industry, 1994-2002. Organ. Stud. 15 537-54.

Holmqvist, M. 2004. Experiential learning processes of exploitation and exploration within and between organizations: An empirical study of product development. Organ. Sci. 15 70-81.

Ireland, R. D., M. A. Hitt, R. A. Bettis, D. A. De Porras. 1987. Strategy formulation processes: Differences in perceptions of strength and weakness indicators and environmental uncertainty by managerial level. Strategic Management J. 8 469-485.

Jaccard, J., R. Turrisi. 2003. Interaction effects in multiple regression, 2nd ed. Sage University Papers Series on Quantitative Applications in the Social Sciences, 07-072, Sage, Thousand Oaks, CA.

Jansen, J. J. P., F. A. J. van den Bosch, H. W. Volberda. 2005. Managing potential and realized absorptive capacity: How do organizational antecedents matter? Acad. Management J. 48 999-1015.

Jansen, J. J. P., F. A. J. van den Bosch, H. W. Volberda. 2006. Exploratory innovation, exploitative innovation, and performance: Effects of organizational antecedents and environmental moderators. Management Sci. 52 1661-1674.

Jaworski, B. J., A. K. Kohli. 1993. Market orientation: Antecedents and consequences. J. Marketing 57 53-70.

Katila, R., G. Ahuja. 2002. Something old, something new: A longitudinal study of search behavior and new product introduction. Acad. Management J. 45 1183-1194.

Lawrence, P. R., J. W. Lorsch. 1967. Organization and Environment: Managing Differentiation and Integration. Harvard Business School Press, Boston.

Leana, C. R., B. Barry. 2000. Stability and change as simultaneous experiences in organizational life. Acad. Management Rev. 25 753-759.

Lewin, A. Y., C. P. Long, T. N. Carroll. 1999. The coevolution of new organizational forms. Organ. Sci. 10 535-550.

Lubatkin, M. H., Z. Simsek, Y. Ling, J. F. Veiga. 2006. Ambidexterity and performance in small- to medium-sized firms: The pivotal role of tom management team behavioral integration. J. Management 32 646-672.

March, J. G. 1991. Exploration and exploitation in organizational learning. Organ. Sci. 2 71-87.

Martinez, J. L., J. C. Jarillo. 1989. The evolution of research on coordination mechanisms in multinational corporations. J. Internat. Bus. Stud. 20 489-514.

McDonough, E. F., R. Leifer. 1983. Using simultaneous structures to cope with uncertainty. Acad. Management J. 26 727-735.

McGrath, R. G. 2001. Exploratory learning, innovative capacity, and managerial oversight. Acad. Management J. 44 118-131.

Miller, D. 1987. Strategy making and structure: Analysis and implications for performance. Acad. Management J. 30 7-32.

Miller, D. 1993. The architecture of simplicity. Acad. Management Rev. 18 644-659.

Miller, D., C. Dröge. 1986. Psychological and traditional dimensions of structure. Admin. Sci. Quart. 31 539-560.

Nadler, D. A., M. L. Tushman. 1987. Strategic Organization Design. Scott Foresman, New York.

Nahapiet, J., S. Ghoshal. 1998. Social capital, intellectual capital, and the organizational advantage. Acad. Management Rev. 23 242-266.

Neter, J., W. Wasserman, M. H. Kutner. 1990. Applied Linear Statistical Models. Homewood, Irwin, IL.

Nonaka, I., N. Konno. 1998. The concept of "ba": Building a foundation for knowledge creation. California Management Rev. 40 40-54.

O'Reilly, C. A., M. L. Tushman. 2004. The ambidextrous organization. Harvard Bus. Rev. 82 74-81.
Organ, D. W., C. N. Greene. 1981. The effects of formalization on professional involvement: A compensatory process approach. Admin. Sci. Quart. 26 237-252.

Papadakis, V. M., S. Lioukas, D. Chambers. 1998. Strategic decisionmaking processes: The role of management and context. Strategic Management J. 19 115-147.

Pierce, J. L., A. L. Delbecq. 1977. Organization structure, individual attitudes and innovation. Acad. Management Rev. 2 27-37.

Podsakoff, P. M., D. W. Organ. 1986. Self-reports in organization research: Problems and prospects. J. Management 40 308-338.

Pugh, D. S., D. J. Hickson, C. R. Hinings, K. M. Macdonald, C. Turner, T. Lupton. 1963. A conceptual scheme for organizational analysis. Admin. Sci. Quart. 8 289-315.

Raisch, S., J. Birkinshaw. 2008. Organizational ambidexterity: Antecedents, outcomes, and moderators. J. Management $\mathbf{3 4}$ 375-409.

Reagans, R., E. W. Zuckerman. 2001. Networks, diversity, and productivity: The social capital of corporate R\&D teams. Organ. Sci. 12 502-517.

Rindfleisch, A., C. Moorman. 2001. The acquisition and utilization of information in new product alliances: A strength-of-ties perspective. J. Marketing 65 1-18.

Rivkin, J. W., N. Siggelkow. 2003. Balancing search and stability: Interdependencies among elements of organizational design. Management Sci. 49 290-311.

Rodan, S., C. Galunic. 2004. More than network structure: How knowledge heterogeneity influences managerial performance and innovativeness. Strategic Management J. 25 541-562.

Rowley, T. J., D. Behrens, D. Krackhardt. 2000. Redundant governance structures: An analysis of structural and relational embeddedness in the steel and semiconductor industries. Strategic Management J. 21 369-386.

Sanchez, R., A. Heene, H. Thomas. 1996. Dynamics of CompetenceBased Competition. John Wiley and Sons, New York.

Sheremata, W. A. 2000. Centrifugal and centripetal forces in radical new product development under time pressure. Acad. Management Rev. 25 389-408.

Smith, K. G., C. J. Collins, K. D. Clark. 2005. Existing knowledge, knowledge creation capability, and the rate of new product introduction in high-technology firms. Acad. Management J. 48 346-357.

Smith, W. K., M. L. Tushman. 2005. Managing strategic contradictions: A top management model for managing innovation streams. Organ. Sci. 16 522-536.

Subramaniam, M., M. A. Youndt. 2005. The influence of intellectual capital on the types of innovative capabilities. Acad. Management J. 48 450-463.

Tsai, W. 2002. Social structure of "coopetition" within a multiunit organization: Coordination, competition, and intraorganizational knowledge sharing. Organ. Sci. 13 179-190.

Tushman, M. L., C. A. O'Reilly. 1996. Ambidextrous organizations: Managing evolutionary and revolutionary change. California Management Rev. 38 8-30.

Uzzi, B. 1997. Social structure and competition in interfirm networks: The paradox of embeddedness. Admin. Sci. Quart. 42 35-67.

Van De Ven, A., A. L. Delbecq, R. Koening. 1976. Determinants of coordination modes within organizations. Amer. Sociol. Rev. 41 322-338.

Walsh, J. P. 1988. Selectivity and selective perception: An investigation of managers' belief structures and information processing. Acad. Management J. 31 873-896.

Whetten, F. R. 1978. Coping with incompatible expectations: An integrated view of role conflict. Admin. Sci. Quart. 23 254-271.

Zander, U., B. Kogut. 1995. Knowledge and the speed of the transfer and imitation of organizational capabilities: An empirical test. Organ. Sci. 6 76-92.

Zmud, R. W. 1982. Diffusion of modern software practices: Influence of centralization and formalization. Management Sci. 28 $1421-1431$. 